\title{
10. The economy
}

\section{ANNE GARNETT AND PHIL LEWIS}

Kevin Rudd claimed to be an economic conservative - a younger version of John Howard - during his campaign to win government in 2007. Rudd's government of two-and-a-half years was, however, characterised by high spending, high debts and ill-fated economic policies and there were also a large number of policy about-turns and failures. The period was also dominated by the global financial crisis (GFC), and Australia was not alone in having to recalibrate its economic strategies to respond to what has been a significant, worldwide phenomenon.

The GFC prompted the government to increase spending to cushion the potential effect on Australia. While both major political parties generally supported the idea of stimulus spending, the amount and form of the spending have been the subject of considerable debate. Rudd took office in 2007 with net government saving of almost $\$ 45$ billion and left office in June 2010 with an estimated net debt of almost $\$ 42$ billion-forecast to increase to almost $\$ 94$ billion by 2012 , with annual interest repayments of more than $\$ 6$ billion. During this time, however, Australia did not experience the rise in unemployment rates or the falls in economic growth rates of the same magnitude as many other countries in the industrialised world. The question is whether this was due to policies of the Rudd government, or whether other factors protected Australia, including a stable and well-regulated financial system, strong growth in the mining sector driven by demand in China and India, and the strong economy, budget surplus and net savings it inherited from the previous, Coalition government.

\section{The GFC}

The GFC largely dictated the fiscal policy direction of the Rudd government. Concerned that the financial crisis experienced in the United States, Europe and parts of Asia would spread to Australia, the Labor government embarked on a series of large economic stimulus measures.

The GFC originated in the United States, as the result of very poor credit standards, high levels of borrowing - arguably assisted by the low interest 
rate policy of the Federal Reserve Bank and enabled by China's surplus of funds - and asset price bubbles (shares and real estate priced higher than their underlying value). The lack of financial regulation by both the US government and its financial sector allowed home loans to be made to an enormous number of households that were not in a position to repay them. People were able to buy homes with no deposit, no employment, very low incomes, poor credit histories, and could, in some instances, borrow up to 110 per cent of the value of their properties. The risk associated with these 'sub-prime mortgages' was spread as they were repackaged and sold as financial assets to other financial institutions in many parts of the world. Therefore, when the inevitable loan defaults began to emerge towards the end of 2007, the impact spread throughout much of the world. Australia's financial system had minimal exposure to these 'toxic' debts due to existing prudential regulations, which were tightened by the former Coalition Treasurer Peter Costello, and due to more responsible lending behaviour and low exposure to risky assets by the majority of Australian banks and financial institutions. In fact, in 2010, the Governor of the Reserve Bank of Australia (RBA), Glenn Stevens, referred to the GFC as a North Atlantic financial crisis. The shortage of credit globally, however, did impact on liquidity and interest rates in Australia, with banks claiming that in 2008 credit shortages were forcing them to increase interest rates on loans.

Following the massive financial institution bailouts, which converted much private debt to public debt, a history of deficits by some governments, and the recent large fiscal stimulus measures, the problem of the GFC has now become a problem of public debts of unprecedented proportions, with some European governments in danger of defaulting. Australia's public debt is large by Australian standards, but relatively small as a proportion of GDP especially when compared with the debts of many other major industrialised countries. When the Rudd government came to power in November 2007, the annual rate of economic growth in Australia was about 4 per cent, following more than 16 years of continual economic growth. Annual growth had slowed to 2.8 per cent by June 2008 and then to 0.3 per cent by June 2009 (ABS 2010a). Economic growth in Australia was negative for only one quarter-December 2008 - which meant that Australia had avoided a recession (often measured as two consecutive quarters of negative economic growth). When compared with the severe recessions experienced by the United States, the United Kingdom and Europe, and parts of Asia, the Australian experience was remarkable. By 2010, Australia's economic recovery was under way, with an annual economic growth rate of 3.2 per cent by June 2010 (ABS 2010a). When Rudd took office in November 2007, the rate of unemployment was 4.3 per cent (ABS 2010d). It rose far less than in many other countries during the GFC, peaking at 5.8 per cent in 2009, and falling back to 5.2 per cent by the time Rudd was replaced as Prime Minister in June 2010 (ABS 2010d). 


\section{Economic stimulus policies}

So how did Australia avoid the recessions experienced in so many other parts of the world? The Rudd government claimed that it was due to its quick and strong economic stimulus measures. Other analysts point to Australia's well-regulated financial system, which had very little exposure to the toxic loans being sold around the world, arguing that Australia was never going to experience many of the effects of the GFC. The strength of the mining sector, driven by demand in China and India, is frequently cited as protecting Australia from significant effects of the crisis. The opposition parties claimed that Australia avoided a recession in large part due to the strength of the economy created during their time in government and the flexibility they had introduced into the labour market.

With the onset of the GFC, the Labor government commenced a range of economic stimulus measures that comprised cash handouts and subsidies and infrastructure building as part of the $\$ 42$ billion Nation Building: Economic Stimulus Plan (Australian Government 2010b). Following the advice from the head of the Commonwealth Treasury, Ken Henry, to 'go hard, go early, go households', Rudd began to implement stimulus measures. In December 2008, cash payments to pensioners and families with children and an increase in the first-home-buyers' grant amounted to $\$ 10.4$ billion. This was then quickly followed by direct cash payments to the majority of taxpayers of up to $\$ 900$ a person in 2009 (Australian Government 2010b). There is no doubt that the large cash handouts and government spending of the Rudd government boosted economic growth and protected some employment during the GFC. The injections increased retail spending, which strengthened during the first half of 2009 (ABS 2010e). Some economists, however, argued that a significant proportion was spent on imported goods and was also saved or used to repay debts, reducing the stimulus effect on the economy. The then Leader of the Opposition, Malcolm Turnbull, argued that the 'cash splash' was 'very little bang for a very big buck' (ABC 2010a).

The other major component of the Labor government's stimulus policy was a series of infrastructure building projects, some of which met with disaster and were subsequently abandoned. These infrastructure and job support programs included new buildings in schools, new public housing and housing upgrades, community infrastructure grants, extra funding for national highway maintenance and rail upgrades, subsidies for households who switched to more energy efficient appliances and a home insulation scheme. 


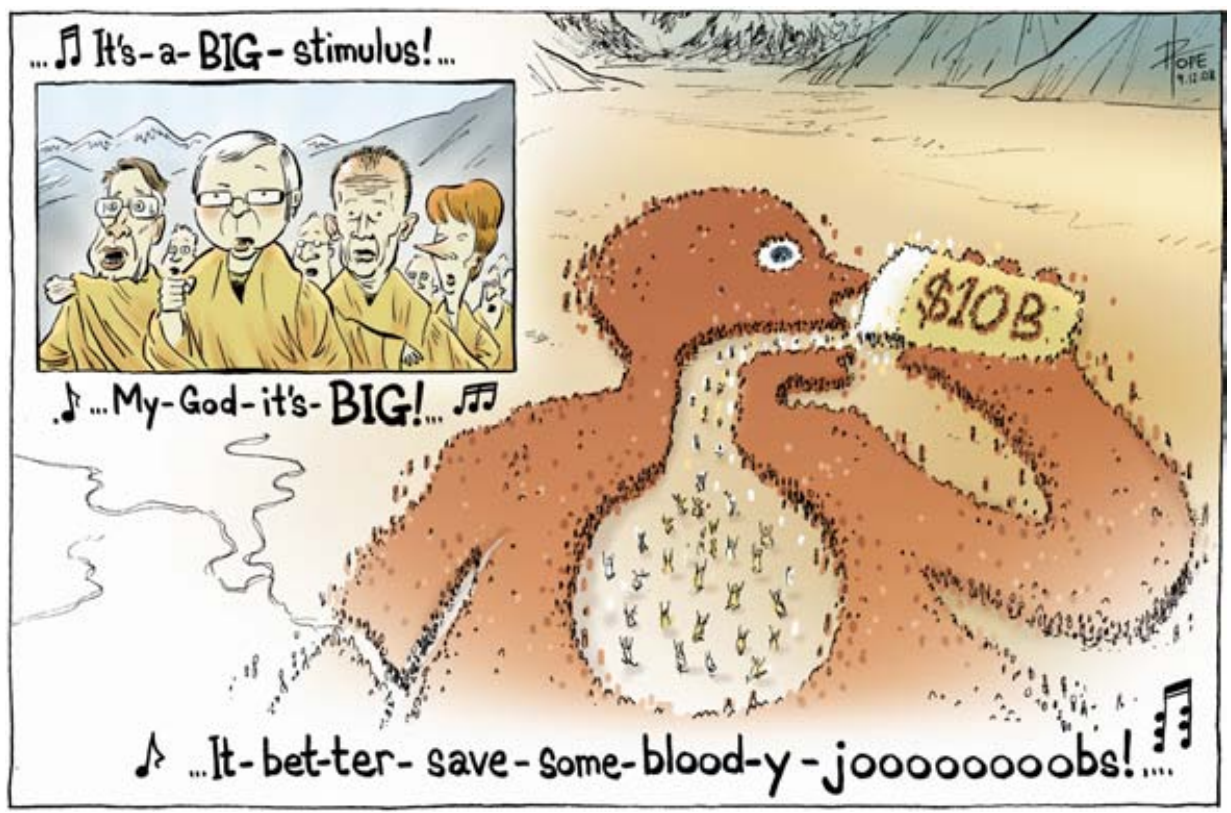

Source: David Pope, The Canberra Times, 9 December 2008

One of the most controversial programs was the disastrous $\$ 2.4$ billion home insulation, or 'pink batts', program, which paid a rebate of $\$ 1200$ a home for the cost of home insulation. Overseen by the then Minister for the Environment, Heritage and the Arts, Peter Garrett, the program aimed to create jobs and to insulate more than two million homes. Serious breaches of safety, however, due to rushed jobs by poorly trained installers, led to four deaths, a number of injuries, 120 house fires and more than 200000 homes with faulty or poorly fitted insulation (The Australian 2010a). The Rudd government was criticised for not acting sooner given the many warning letters from businesses within the insulation industry and from state governments regarding the lack of monitoring of workers' qualifications and safety standards. The program began in July 2009 and was axed in February 2010. It was then followed by a long safety inspection program for homes fitted with foil insulation - at an estimated cost of about \$1 billion (The Australian 2010a).

The Building the Education Revolution (BER) 'school halls' program was another major component of the Labor government's stimulus policies, implemented by the then Minister for Education, Julia Gillard. It aimed to provide rapid construction of multi-purpose halls and libraries to stimulate the building industry while at the same time providing improved facilities for schools. The largest component of this policy was $\$ 12.4$ billion of capital works in primary schools, which became $\$ 14.1$ billion due to cost increases of $\$ 1.7$ billion (ANAO 2010). The scheme became the subject of significant criticism with claims of 
rorts and hugely inflated building prices. It was argued by some schools that the scheme lacked flexibility and that they were receiving buildings they did not need. The involvement of state and territory government administration added much to costs, managing contractors were charging more than three times the usual fee, the time frame for construction completion was too short, and some local builders were greatly inflating prices (The Australian 2010b). For example, in March 2010, lobbying by a school principal led the NSW state government to finally reverse a decision to spend $\$ 1$ million on a shade-cloth structure (originally quoted as costing $\$ 400000$ ), which was valued at market prices at only $\$ 250000$ (The Australian 2010b). In Parramatta, a school hall was built in a private school for $\$ 170000$, and in a BER-funded public school a similar hall was built for $\$ 350$ 000. In 2009 and 2010 in Queensland, more than 20 per cent of the BER was being absorbed in administration costs (The Australian 2010b). The widespread extent of the apparent price gouging led to audits commencing in 2010, conducted by state governments and the Australian National Audit Office (ANAO). As the BER program was scheduled to run until 2012, serious concerns began to arise that the waste was going to be even greater than in the insulation program. Following much public outcry, in May 2010, Julia Gillard set up the government's own task force to investigate formal claims of waste and rorting in the BER. There were, however, also accusations of waste even within the task force, with more than $\$ 1$ million spent on consultants within the first two months, and a total budget allocation for the task force of \$14 million (ABC 2010b). An additional problem emerged with the sudden and large demand for building materials and labour for the BER flowing through to higher prices in non-school construction, and increasing costs in other industries.

Many schools, however, reported that the building programs were useful, and formal complaints were made by about only 3 per cent of schools (Australian Government 2010a). The building industry also received a boost in profits and employment. The key question is whether or not the BER represented value for money, and whether the stimulus effects justified the waste and government debt. This is, of course, the same question facing the entire Nation Building program. Economists and analysts generally acknowledge that some stimulus was required to help shield Australia from the effects of the GFC, and that the speed of the Rudd government's policy response was instrumental in its early impact on the economy. The debate centres on whether the size of the economic stimulus was appropriate or too big, the way in which the funds were used, the size of the ensuing government debt, and on whether the stimulus measures should have been wound back faster once economic growth returned to healthy levels. 


\section{Government spending, budgets and debt}

The Rudd government came to office at a time when the Australian economy had achieved its lowest rate of unemployment in more than 30 years and economic growth was strong. The Commonwealth budget was in surplus by about $\$ 20$ billion and the government was one of the very few in the world that had net savings - about $\$ 45$ billion-instead of large net debt levels (Australian Government 2010c). As part of Labor's 2007 election campaign, Rudd promised that his government would be fiscally conservative and would keep the budget in surplus. Interestingly, achieving a balanced or surplus budget again became an important objective for both sides of Parliament in the 2010 federal election, indicating that a surplus budget has now become a very important issue with voters. The strong emphasis on a surplus budget is a relatively new objective for Labor, and, as Figure 10.1 shows, from the mid-1970s to the mid-1990s, the budget was more often in deficit than in surplus. It was clear, however, that despite the fiscally conservative pitch, the Rudd government remained less concerned than the Coalition about increasing government spending and the consequent debt, with Rudd arguing in favour of 'classic Keynesianism' spending during the GFC (Rudd 2009).

The Rudd government commenced governing with the intent of balancing budgets, but this aim was no longer possible following the large GFC fiscal stimulus policies, and was further exacerbated by significant policy cost blowouts. In addition to the stimulus policies discussed earlier, a number of other policies exceeded budget forecasts, including the provision of laptop computers in schools; the solar panel rebate - so successful that it exceeded its budget and had to be ended early; the Green Loans Scheme-cancelled in 2010 due to allegations of rorting (The Australian Greens 2010); the Indigenous housing program; and Grocery Choice (axed in 2009). Figure 10.1 shows that the Rudd government's budget deficit is large by historical standards, moving from a surplus of close to $\$ 20$ billion in June 2007 to a deficit of about $\$ 55$ billion in June 2010 (Australian Government 2010c). When expressed as a percentage of GDP, the deficit in 2010 is the largest in more than four decades, at 4.4 per cent of GDP.

As indicated earlier in this chapter, there is little doubt that the Rudd government's stimulus spending cushioned Australia from the impact of the GFC, preventing the rate of economic growth from falling as far as it might otherwise have done. By the end of Rudd's term, however, questions were being asked by some economists and analysts as to whether or not Australia was actually going to be significantly affected by the GFC, whether the stimulus spending was appropriate in size and gave value for money, and why the stimulus programs were continuing until 2012 even though the threat of recession was clearly over. 
The stimulus spending involved substantial government borrowing, with net government debt forecast to rise to almost $\$ 94$ billion by 2012 , with annual interest repayments of more than $\$ 6$ billion (Australian Government 2010c). This represents about 6 per cent of GDP, which is substantially lower than the debts incurred by the Labor government in the 1980s and early 1990s, which peaked at 18 per cent of GDP in 1996.

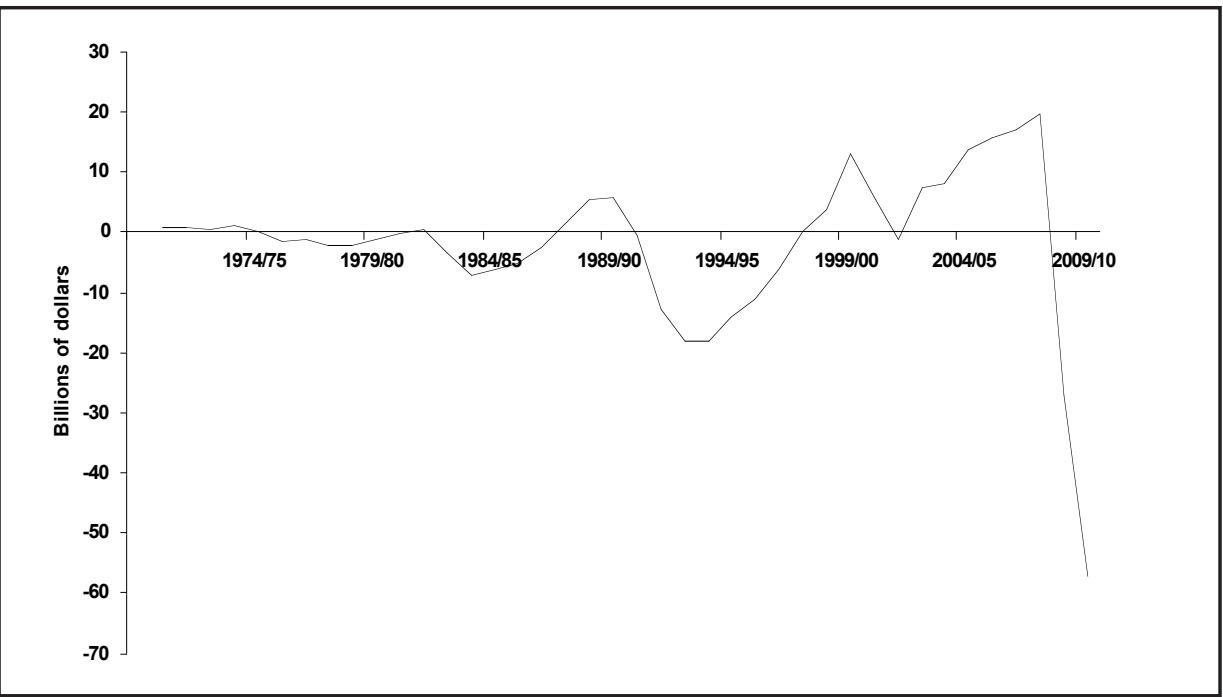

Figure 10.1 Commonwealth government budget: surpluses and deficits, 1970-71 to 2009-10

Source: Australian Government (2010c).

It should be remembered that borrowing during an economic downturn or recession is normal and even expected, as tax receipts are down and spending increases to fund payments for unemployment benefits and pensions. An important economic issue is that government borrowing carries with it a future burden in the form of higher taxes and reduced government services, as the debt must be repaid, with interest. If borrowing is used in ways that will increase the future productivity of the economy, such as a better educated workforce and improved infrastructure, future economic growth will enable the repayment of the debt without imposing a significant burden on the country. If government borrowing is used for non-productive purposes, such as cash handouts and programs dominated by waste, the future burden is much greater. It is likely that the Labor government's debts have led to a mix of both outcomes: some improvements in the productive capacity of the economy, together with a significant amount of waste.

Government borrowing also puts upward pressure on interest rates, and this has effects on the private sector. Prior to the GFC, the RBA was increasing interest 
rates, believing that the Australian economy was in danger of overheating and that the rate of inflation would then accelerate. During the boom years of the 2000s, the RBA increased the official cash rate (the rate set by the RBA upon which all other interest rates are based) from a low of 4.25 per cent in December 2001 to a high of 7.25 per cent in March 2008 (RBA 2010). When the extent of the GFC was realised, the RBA rapidly reduced the cash rate to a low of 3 per cent in April 2009, with some economists crediting the RBA's rapid and significant action with preventing a recession in Australia. After April 2009, the cash rate was increased on six separate occasions, to 4.5 per cent by the end of the Rudd government's term (RBA 2010). While economic recovery allowed the RBA to begin to return interest rates from an expansionary stance to a more neutral stance, government borrowing also put upward pressure on interest rates. By 2010 , the Labor government was borrowing more than $\$ 1$ million each day and continuing its stimulus programs - even though the economic growth rate had returned to a healthy level and was forecast by the Governor of the RBA to remain healthy (Stevens 2010). The continued stimulus spending put upward pressure on inflation, leading the RBA to raise interest rates by more than it otherwise would need to. This then meant that the private sector faced higher interest rates, which discourages private investment and economic activitythe crowding-out effect.

The rush to accumulate debt to finance marginal short-term infrastructure spending contrasted with the pressing need for investment expenditure to improve Australia's wealth-creating activities in response to mining booms, population growth, skills shortages and transport. Unfortunately, these are the direct responsibility of the states and territories (most with Labor governments), although funding is often delivered by the Commonwealth. The failure of most states and territories to keep pace with infrastructure needs - particularly New South Wales - has led to significant price rises for many services, particularly water and electricity, which have mainly fuelled inflation while price rises for most other goods and services in the economy have been relatively modest.

\section{The labour market}

The Rudd government inherited one of the best-performing labour markets in the world; in 2007 the unemployment rate reached a 33-year national low of 4.3 per cent, and in some states and territories, particularly Western Australia and the Australian Capital Territory, unemployment rates of approximately 2 per cent were recorded. Despite this relatively rosy picture of the Australian labour market, more than 1.2 million people of working age rely on social security payments as their major means of income, representing a major source of potential labour supply (Lewis 2008). In examining the labour market during 
the latter years of the Howard government, one of the biggest issues facing the Australian economy was a shortage of labour. These shortages arose in both the private and public sectors, in both skilled and unskilled labour. This particularly affected the numbers of professionals such as medical practitioners, nurses, schoolteachers, pilots, economists, tradespeople and engineers through to agricultural workers and shop assistants (Lewis 2008). As an economy nears full employment, bottlenecks in certain parts of the economy are expected, as economic growth and structural change are not evenly spread throughout the economy and some industries can adjust quicker than others. Specific labour shortages continued during Rudd's term, even during the GFC.

One attempt to alleviate this was to increase the intake of migrants and temporary residents. In 2006 the net inflow of new migrants was 134600 - up 23 per cent from 2003 - and there was a net addition of more than 200000 longstay arrivals over departures (ABS 2007). Under the Rudd government, planned migration rose by 7 per cent and 8 per cent, respectively, in the financial years 2007-08 and 2008-09. In addition, at the peak of 2009 there were 146600 temporary business, 116800 working holiday and 434000 student visa-holders in Australia (DIAC 2009). Overall, workers from overseas made up about 8 per cent of the workforce.

It is rather strange, given the role that immigration played in meeting Australia's labour shortages, that, as the economy resumed its growth path following the GFC, both major political parties went to the 2010 election on a platform of reducing migration! Yet again, issues requiring well thought-out discussionsuch as population growth, workforce needs, skills policy and infrastructure requirements - were reduced to a largely nonsensical slanging match about numbers. The perceived excess demand for labour took the policy focus away from unemployment. Indeed Labor's Treasurer, Wayne Swan, boasted in his budget speech of May 2010 that the government was within striking distance of achieving full employment (Swan 2010). He said full employment was consistent with a rate of 4.75 per cent. It seemed to be an indictment on a Labor government that such a large proportion of the population had not found useful work and that, with all the social problems this entails, it could be referred to as 'full employment'. Successive Coalition and Labor governments have failed to bring about reform of social security, education and training, and the labour market (particularly the minimum wage) necessary to get the unemployment rate down to 1970s levels of about 2 per cent, and necessary to move more than 1.2 million people from welfare to work. The more appropriate interpretation of the magic 4.75 per cent is that when the unemployment rate reaches something like this level, bottlenecks in certain labour markets begin to arise and employers find it difficult to recruit labour. This puts pressure on wages to rise and therefore 
raises fears about inflation. Hence labour market reforms and reforms in other markets are essential if the unemployment rate is to be lowered without leading to wage and price inflation.

\section{Industrial relations}

Workplace industrial relations was one of the defining issues in the 2007 federal election. The possibility of the return of WorkChoices - the former Howard government's labour market reforms - was still being played as a major card by Labor in the 2010 election campaign. The Rudd government's Fair Work Australia was set up as an alternative that would wind back many of the most feared parts of WorkChoices. On 1 July 2009, Fair Work Australia began operations as part of a new national workplace relations system underpinned by the Fair Work Act 2009. The new system, which also includes the Office of the Fair Work Ombudsman and Fair Work divisions of the Federal Court and Federal Magistrate's Court, was introduced in stages and replaced that which operated under WorkChoices. The key feature of Fair Work Australia was the abolition of the Australian Fair Pay Commission, the Office of the Employment Advocate, the Office of Workplace Services and the Industrial Relations Commission, bringing their functions together under Fair Work Australia. There was also the return of much of the 'unfair' dismissal provisions axed under WorkChoices. The main points contained in the Fair Work Act 2009 are

- enterprise bargaining and awards to be the main bases of wage determination

- Australian Workplace Agreements (AWAs) abolished and existing AWAs fazed out by 2012

- individuals earning more than $\$ 100000$ may negotiate employment contracts without reference to awards

- safety-net minimum conditions expanded from six to 10

- secondary boycotts to remain outlawed

- no pattern bargaining

- restrictions on union officials' right of entry to workplaces to remain

- unfair-dismissal claims may be made after 12 months' employment in firms with fewer than 15 employees and after six months in firms with 15 or more employees.

While Rudd's industrial relations 'reforms' reversed the most hated parts of WorkChoices, they also reversed many of the earlier changes brought in by the Hawke-Keating and Howard-Reith reforms to industrial relations, which had reduced the influence of unions and tribunals in wage setting and dispute resolution. It is still too early to evaluate the impacts of all the workplace 
changes, but the major complaint by employers, particularly small business, is the reduction in flexibility in employment. The most obvious, and widely publicised, example is the loss of jobs for school students who are no longer able to work after school because under workplace legislation it is illegal to employ anyone for less than a three-hour shift! The benefits of increased labour market flexibility under Hawke-Keating and Howard-Reith were best evidenced by the failure of unemployment to rise as much as predicted after the GFC. Many employers and employees adopted flexible responses to the economic downturn such as taking leave, reducing hours and shifting to part-time work. In effect, employees took wage cuts because the reduction in their hours of work was more than the reduced output, reducing the cost of labour per unit of output. The willingness of workers to accept cuts would not have been expected in the days before labour flexibility, as evidenced by union responses to the recessions of the 1970s. Added worker compliance was probably the result of the experience of employers coming out of a period of labour shortage, not wishing to lose workers only to have to face recruitment difficulties during the recovery. Of great interest will be the impact of the Rudd government's increased labour market regulation when the economy achieves low unemployment rates.

\section{Taxation reform}

The Rudd government was forced to implement the reductions in personal income tax of former Coalition Treasurer Peter Costello, due to the promise made during Labor's 2007 election campaign. Labor's Treasurer, Wayne Swan, however, went a long way to reversing the concessions to those who salary sacrificed into superannuation. The biggest news stories on taxation related to the Henry Tax Review, which was completed in December 2009, but the report of which was withheld from the public until May 2010. This was to be the most significant 'root and branch' review of taxation in Australia, at least since the Campbell inquiry. The head of Treasury, Ken Henry, produced a comprehensive report based on sound economic principles. Perhaps inevitably, good economics is not always compatible with popular politics, as Labor adopted only three of the 138 recommendations, the most controversial being the Resource Super Profits Tax (RSPT). The government also proposed one measure opposed by the review: raising the percentage of compulsory superannuation contributions.

There are several criteria generally used by economists to evaluate taxes: equity, allocative efficiency, simplicity and inability to evade (Lewis et al. 2010). The argument for resource rent taxes, like many taxes, such as a broad-based goods and services tax (GST), is hard to dispute on the basis of these criteria. As with the GST, however, the details, the response of vested interests and the selling of the tax to the public are all important. The RSPT was to apply a 40 per 
cent tax on mining profits, in addition to the usual company income tax (Swan 2010). Mining companies would be allowed to subtract a tax-free allowance (normal profit) at the long-term bond rate (approximately 6 per cent) from their existing earnings. The Federal Government would refund the royalties that resource companies have to pay to states and territories. Importantly, the RSPT proposals allowed for 40 per cent of any losses to be either claimed back from the government as a refund or carried over to other projects. In effect, the government was to become an equity partner in resource projects bearing 40 per cent of all costs and 40 per cent of all economic rents.

Several commentators put forward the view that Rudd believed the RSPT to be a sure winner with the electorate. After all, who could argue with sound economics and who would not want the nation to get its fair share of excessive mining profits? The massive anti-tax campaign of the mining companies, which was very damaging to Rudd and the Labor Party, was a lesson in politics. Kevin Rudd and his inner cabinet made a huge mistake in putting forward a major tax change without prior consultation with the industry concerned, without calling for public submissions, and without Rudd even consulting most of his own ministers. As soon as she became Prime Minister, Julia Gillard took on the job of negotiating with the big mining companies and, on 2 July 2010, she announced that the Minerals Resource Rent Tax (MRRT) would replace the RSPT. The new tax would apply only to the iron ore and coal industries; and the tax rate was reduced from 40 per cent in the RSPT to 30 per cent, levied on 75 per cent of net profit. The rate for losses carried forward and used royalty credits was increased to 7 per cent above the long-term government bond rate. The government claimed that only $\$ 1.5$ billion less revenue would be raised under the MRRT, but many commentators put the revenue loss at more than $\$ 4.5$ billion, even under extremely conservative assumptions (see, for instance, Knight 2010), with some estimates rising up to $\$ 20$ billion (Probyn and Wright 2010).

Another tax issue, although it was not described as such, was the emissions trading scheme (ETS) - a defining feature of the Rudd period. The purpose of an ETS is to reduce the use of carbon by households and firms because of the view that burning carbon causes environmental damage - climate change. To reduce carbon use, using carbon needs to be made more costly and the simplest way to do this is through a tax on carbon. This, however, raises the prices of coal, gas and electricity and the price of goods that use these resources as inputs (as the Leader of the Opposition, Tony Abbott, frequently expressed it in 2010: 'A great big new tax on everything'). The Rudd government was not very successful at getting this point across; as with the GST, with an ETS, prices would rise but losers can always be compensated. The ETS as originally proposed was quite economically elegant. The option adopted by Rudd, however, was more 
complex, containing large amounts of compensation to reduce the effects on costs and prices (which is counter-intuitive to the purpose of reducing carbon emissions), and ensured that few people would understand it. The ETS was ultimately rejected in the Senate and, instead of continuing with his fight for a carbon reduction scheme, in April 2010, Rudd postponed the proposal until at least 2012 or 2013. The electoral backlash for Rudd was intense, and was a major contributing factor in his removal as Prime Minister (van Onselen 2010). (The issue of climate change is discussed in detail in Chapter 11 of this volume.)

\section{International trade and the balance of payments}

Australia is a relatively free trading nation, with minimal trade or foreign investment barriers. This differentiates it from most other countries, many of which heavily protect their local industries with subsidies, and with tariffs and quotas on imported goods, making their local industries more inefficient and uncompetitive. As a small economy with insufficient savings to fund investment, Australia relies on foreign investment and loans to provide the funding and capital to enable investment and continued economic growth. The interest repayments on these overseas borrowings are measured as a negative item in Australia's current account of its balance of payments, and make up such a large component that it means that Australia will always operate with a current account deficit. Dividends paid on portfolio investment from overseas also represent an outflow of funds, further increasing the current account deficit. Interestingly, the balance between export earnings and import payments - the balance of trade - even when positive, as it was at times during 2009 and 2010 due to a rise in minerals exports, is never sufficient to bring the current account into a surplus. While the balance of trade was a positive $\$ 3.5$ billion in June 2010, the current account deficit remained in deficit (ABS 2010c). Regardless of whether Australia has a positive or negative balance of trade, it is likely to always have a current account deficit due to the interest repayments on borrowings from overseas.

During the period of the Rudd government, the minerals and energy export boom continued, with the industry making up about 56 per cent of total exports near the time when Rudd was replaced (ABS 2010b). As usual, the demand for minerals and energy had almost nothing to do with internal policy and much to do with the very strong demand for coal, liquefied natural gas (LNG) and iron ore in China, India and other emerging economies. For example, between 2007-08 and 2009-10, the value of coal exports rose by almost 46 per cent - a combination of increased volume and higher prices (ABARE 2010). The strength in mineral exports undoubtedly helped to temper the effects of the GFC on the Australian economy. The rate of growth in exports slowed significantly in 200708, but increased again during the following year, as China began to recover 
more quickly from the effects of the financial crisis than many analysts expected. Overall, the current account deficit fluctuated wildly - as is common - during the period of the Rudd government, from deficits of about $\$ 59$ billion in mid2007 and $\$ 73.1$ billion in June 2008 to $\$ 37.5$ billion in June 2009 and a deficit of approximately $\$ 56.1$ billion in June 2010 (ABS 2010b).

While the demand for mineral exports grew, the growing strength of the Australian dollar during the latter part of Rudd's leadership put downward pressure on export earnings in other sectors of the Australian economy. The rural sector-only just beginning to recover from the severe droughts of the early to mid-2000s - was dealt a major blow by the stronger exchange rates, which significantly reduced income from exports. Australia's relatively high interest rates compared with interest rates in many other countries during the GFC increased the demand for Australian dollars, contributing to a higher exchange rate. As discussed earlier, the commencement of significant amounts of government borrowing by the Rudd government to fund its spending policies put further upward pressure on interest rates. Unlike parts of the mining sector, the rural, manufacturing and services sectors face much competition in international markets and are largely price takers, unable to affect the price received for exports in international markets.

\section{Living standards and income distribution}

Labor governments have usually been associated with protecting or promoting the interests of the worse off, in comparison with the Coalition parties. Therefore, it is interesting to compare the term of the Rudd government with that of the Hawke-Keating and Howard governments with respect to income distribution.

Income distribution is usually measured in terms of equivalised disposable household income (Lewis et al. 2010). According to the Australian Bureau of Statistics (ABS), the real average equivalised disposable household income in 2007-08 was \$811 a week, which was almost 26 per cent higher than in 2005-06, at \$644 a week (ABS 2009). The median, however, says nothing about the distribution of earnings.

Table 10.1 provides some internationally recognised measures of income inequality based on measures of equivalised disposable household income. The P20/P50 ratio is the ratio of the earnings of the lowest quintile of income recipients (the bottom 20 per cent) to median earnings. The ABS classification of 'low incomes' excludes the bottom 10 per cent due to difficulties with unreported income. The P80/P20 ratio is the ratio of the highest 20 per cent of income recipients to that of the lowest 20 per cent of income recipients and so on. The Gini coefficient is a summary measure of inequality, between 0 and 1 , and the lower its value, the higher is the degree of inequality. 
It appears that there has been no significant change in income inequality from the mid-1990s to 2007-08. This contrasts with the observed earnings inequality arising from labour markets where demand and wages for those with higher skills and training have grown at a faster rate than for those with lower skills (Lewis et al. 2004). The reason for the unchanged distribution of income during the Howard era was the relative generosity of the Howard government with respect to pensions (but not unemployment benefits) and increased payments to families with children, which also benefited low and middle-income earners (Lewis 2006).

The Rudd government significantly increased pensions in 2010 beyond indexation - by $\$ 29.20$ for singles and $\$ 44$ for couples (Macklin 2010). A factor affecting the lowest-paid employees was the decision (its last) by the Australian Fair Pay Commission to not increase the minimum wage at all in July 2008. This meant that real wages for this group of workers fell in real terms. Fair Work Australia increased the minimum wage by $\$ 20$ a week in 2010 but this did not match the rise in the cost of living between 2008 and 2010. Although the relevant statistics are not yet available, it is likely that under Rudd and Gillard, the lowest-paid employed will have been made worse off. The lower pay would have stimulated demand and employment somewhat but would also, given pension increases, have further exacerbated the growth of pensioners rather than growth in the numbers seeking work.

Table 10.1 Selected income distribution indicators: equivalised disposable household income

\begin{tabular}{l|l|l|l}
\hline & $1995-96$ & $2005-06$ & 2007-08 \\
\hline $\begin{array}{l}\text { Ratio of incomes at top of selected } \\
\text { income percentiles (P) }\end{array}$ & & & \\
\hline P20/P50 ratio & 0.61 & 0.60 & 0.59 \\
\hline P80/P50 ratio & 1.57 & 1.54 & 1.56 \\
\hline P80/P20 ratio & 2.58 & 2.58 & 2.63 \\
\hline $\begin{array}{l}\text { Percentage share of total income } \\
\text { received by persons according to } \\
\text { income category }\end{array}$ & & & \\
\hline Low income & & & \\
\hline Middle income $^{(b)}$ & 11.0 & 10.4 & 10.1 \\
\hline High income $^{(\mathrm{c})}$ & 17.7 & 17.4 & 17.0 \\
\hline Gini coefficient $^{\text {La }}$ & 37.3 & 39.2 & 40.5 \\
\hline
\end{tabular}

(a) persons in the second and third income deciles

(b) persons in the middle-income quintile

(c) persons in the highest-income quintile

Source: ABS (2009). 


\section{Conclusion}

The major economic focus on the Rudd government has been on its handling of the economy during the GFC. The second focus was on the taxation of resources and the ETS. The evaluation of the impact of the stimulus package on jobs and growth is unlikely to be settled empirically and, as with many debates in economics, views will, to a large extent, depend on the politics and the economic doctrine adhered to. The GFC certainly caused a revival of Keynesian sentiment throughout the world and Australia was no exception. In all probability the stimulus package did have some short-run effect in preventing unemployment rising more than it otherwise would have, but much of the spending was wasteful and could have damaged long-term economic growth.

The failure of the ETS and the RSPT to be legislated was symptomatic of the Rudd government's very poor performance in delivering economic policy. The contrast with the slow, gradual process by which the GST was introduced by the former Coalition government from its inception to implementation is a lesson other politicians could well learn.

Anne Garnett is a senior lecturer in economics at Murdoch University and a Research Fellow at the Centre for Labour Market Research.

Phil Lewis is Director of the Centre for Labour Market Research and Professor of Economics at the University of Canberra.

\section{References}

Australian Broadcasting Corporation (ABC) 2010a. 'Sales surge slows stimulus success', ABC News, 6 May 2010, <www.abc.net.au>

Australian Broadcasting Corporation (ABC) 2010b. 'Labor defends BER consult costs', $A B C$ News, 4 August 2010, <www.abc.net.au>

Australian Bureau of Agricultural and Resource Economics (ABARE) 2010. Australian Commodities, vol. 17, no. 2 (June quarter), Australian Bureau of Agricultural and Resource Economics, Canberra, <www.abare.gov.au>

Australian Bureau of Statistics (ABS) 2007. Migration, Australia, 2005-06, Cat. No. 3412.0, Australian Bureau of Statistics, Canberra.

Australian Bureau of Statistics (ABS) 2009. Household Income and Income Distribution, Cat. No. 6523.0, Australian Bureau of Statistics, Canberra. 
Australian Bureau of Statistics (ABS) 2010a. 'Australian National Accounts: national income, expenditure and product', Time Series Workbook, Cat. No. 5206.0, Australian Bureau of Statistics, Canberra, <www.abs.gov.au>

Australian Bureau of Statistics (ABS) 2010b. Balance of Payments and International Investment Position, Australia, Cat. No. 5302.0, Australian Bureau of Statistics, Canberra.

Australian Bureau of Statistics (ABS) 2010c. International Trade in Goods and Services, Cat. No. 5368.0, June, Australian Bureau of Statistics, Canberra.

Australian Bureau of Statistics (ABS) 2010d. 'Labour Force, Australia', Time Series Workbook, Cat. No. 6202.0, Australian Bureau of Statistics, Canberra, Table 1, <www.abs.gov.au>

Australian Bureau of Statistics (ABS) 2010e. 'Retail Trade, Australia', Time Series Workbook, Cat. No. 8501.0, Australian Bureau of Statistics, Canberra, Table $2,<$ www.abs.gov.au>

Australian Government 2010a. Building the Education Revolution Implementation Taskforce: Interim report, Commonwealth of Australia, Canberra.

Australian Government 2010b. Nation Building-Economic Stimulus Plan, Commonwealth of Australia, Canberra, <www.economicstimulusplan.gov. $\mathrm{au}>$

Australian Government 2010c. Statement 10: historical Australian government data, Budget Paper No. 1: Budget Strategy and Outlook 2010-11, Commonwealth of Australia, Canberra, <www.budget.gov.au/2010-11>

Australian National Audit Office (ANAO) 2010. Building the Education Revolution: primary schools for the 21st century, The Auditor General Audit Report No. 33 2009-10 Performance Audit, Australian National Audit Office, Canberra.

Department of Immigration and Citizenship (DIAC) 2009. Immigration Update July to December 2009, Department of Immigration and Citizenship, Commonwealth of Australia, Canberra.

Knight, E. 2010. 'Smoke and mirrors trick with resources tax', Sydney Morning Herald, 7 July 2010.

Lewis, P. 2006. Minimum wages and employment, Research Report 1/06, Australian Fair Pay Commission, Melbourne.

Lewis, P. 2008. The labour market, skills demand and skills formation, Research Report No. 6, The Academy of Social Sciences in Australia, Canberra. 
Lewis, P., Daly, A. and Fleming, D. 2004. 'Why study economics? The private rate of return to an economics degree', Economic Papers, vol. 23, no. 3, pp. 234-43.

Lewis, P., Garnett, A., Treadgold, M. and Hawtrey, K. 2010. The Australian Economy: Your guide, (Fifth edition), Pearson Australia, Sydney.

Macklin, J. 2010. 'Pensions to increase on $20 \mathrm{March}^{\prime}$, Australian Labor News, <www.alp.org.au/federal-government/news >

Probyn, A. and Wright, S. 2010. 'Billion-dollar bungle that saved mine deal', West Australian, 3 July 2010, p. 1.

Reserve Bank of Australia (RBA) 2010. Cash Rate Target - Interest rate decisions, Reserve Bank of Australia, Sydney, <www.rba.gov.au>

Rudd, K. 2009. 'The global financial crisis', The Monthly, February, pp. 20-9, $<$ www.themonthly.com.au $>$

Stevens, G. 2010. Monetary policy and the regions, Address to Foodbowl Unlimited Forum Business Luncheon, Shepparton, Vic., 20 September, $<$ www.rba.gov.au/speeches/2010>

Swan, W. 2010. Budget speech, Budget 2010-11, Commonwealth of Australia, Canberra, <www.budget.gov.au>

The Australian 2010a. '\$1 bn to fix PM's insulation debacle', The Australian, 23 April 2010.

The Australian 2010b. 'School building shapes as bigger debacle than batts', The Australian, 1 April 2010.

The Australian Greens 2010. Green Loan Scheme debacle-matter of public importance speech, 3 February, <http://greensmps.org.au >

van Onselen, P. 2010. 'Politics trumps a moral challenge', The Australian, 29 April 2010, <www.theaustralian.com.au/news> 